\begin{tabular}{|l|l|l|l|l|l|}
\hline J. Tek. Ling & Vol.11 & No.1 & Hal. 7 - 26 & Jakarta, Januari 2010 & ISSN 1441-318X \\
\hline
\end{tabular}

\title{
PROTOTIPE INSTALASI PENGOLAHAN AIR LIMBAH INDUSTRI PENGOLAHAN IKAN DI KECAMATAN MUNCAR, KABUPATEN BANYUWANGI
}

\author{
Setiyono dan Satmoko Yudo \\ Pusat Teknologi Lingkungan, BPP Teknologi \\ JI. MH. Thamrin No. 8 Jakarta
}

\begin{abstract}
Muncar region known as the area of the fish and the fish processing industry. Many of the fish processing industries in large scale, small scale and household at this time growing so rapidly. With the rapid growth of the fish processing industry in the Muncar city has provided a very significant impact on the city growth, which eventually brought the various impacts, whether they are positive or negative. One of the negative impact of processing industry growth in Muncar is environmental of pollution is the discharge of liquid waste from industrial fish-processing industry. Low level of understanding IPAL waste management system and cause difficulties to manage the waste, therefore almost all waste that generated in the region immediately removed to the public channels. Waste disposal without treatment is causing high level of environmental pollution in the vicinity of the location of industry.

One effort to solve the problem of waste-processing technology is determine processing of waste water and fish processing, it has been done to test prototype installation processing waste water in one of the fish processing industry in the Muncar District.
\end{abstract}

Key words : fish processing industry waste water, environmetal pollution, waste water processing prototype.

\section{PENDAHULUAN}

Upaya pengendalian pencemaran di Indonesia sampai saat ini masih mengalami banyak kendala. Sebagian dari penghasil bahan pencemar masih belum melakukan pengolahan terhadap limbahnya karena adanya berbagai kendala antara lain kurangnya kesadaran bahwa pengelolaan limbah merupakan investasi jangka panjang yang harus dilakukan, kurangnya informasi teknologi IPAL yang efektif dan efisien serta kurangnya sumber daya manusia yang menguasai teknologi IPAL.

Akhir-akhir ini kerisauan masyarakat akibat pencemaran lingkungan telah mencapai tingkat yang mencemaskan. Banyak ahli berdiskusi tentang hal tersebut, namun permasalahan masih terus berlangsung. Kerisauan akan makin bertambah jika penanganan permasalahan tidak kunjung selesai meskipun berbagai proyek penanggulangan telah menghabiskan dana milyaran rupiah. Hal-hal seperti ini akan menyulut ke persoalan sosial yang rumit antara penghasil limbah, masyarakat yang terkena dampak dan para pihak yang telah memberikan proyek penanggulangan, apalagi jika dana diambil dari dana masyarakat atau pemerintah.

Di kota-kota besar seperti Jakarta, Surabaya, Medan dan lainnya, pencemaran lingkungan oleh limbah merupakan satu masalah yang sangat serius dan perlu 
segera ditangani. Kawasan industri, baik industri manufakturing maupun industri jasa seperti hotel, pusat perbelanjaan dan komplek perkantoran merupakan pusatpusat aktivitas yang banyak menghasilkan air limbah. Air limbah yang dibuang tanpa diolah terlebih dahulu telah mengakibatkan meningkatnya pencemaran lingkungan dan menurunnya kualitas air, tanah dan kualitas udara. Untuk menghindari terjadinya dampak pencemaran yang lebih berbahaya lagi, maka pemerintah telah menetapkan agar semua unit-unit usaha diatas mengolah limbah yang dihasilkannya sampai memenuhi baku mutu yang ditetapkan sebelum dibuang ke lingkungan perairan disekitarnya ${ }^{1}$. Dengan demikian diharapkan dampak pencemaran lingkungan yang lebih besar lagi akibat buangan limbah industri dapat dihindarkan, dan lebih jauh lagi slogan pembangunan yang berkelanjutan dapat terealisasi dengan baik.

Salah satu industri yang berkembang secara alami adalah industri pengolahan ikan di Kecamatan Muncar, Kabupaten Banyuwangi. Pada awalnya Industri ini merupakan industri kecil, tetapi saat ini sebagian dari industri ini saat ini telah berkembang menjadi industri besar yang berorientasi ekspor.

Industri pengolahan ikan merupakan industri yang banyak menggunakan air untuk proses produksinya, sehingga limbah industri ini jumlahnya sangat besar. Disamping itu kadar polutan limbah tersebut relatif sangat tinggi, jadi meskipun polutan yang ada merupakan bahan organik, tetapi karena konsentrasinya yang tingggi dan jumlahnya yang besar, maka jika ingin melakukan pengolahan limbah sampai memenuhi baku mutu, diperlukan biaya investasi maupun operasional yang cukup besar pula. Hal ini akan menyulitkan bagi para pengusaha kecil karena terbatasnya modal usahanya.

Rendahnya tingkat pemahaman IPAL dan sistem manajemen limbah menyebabkan sulitnya untuk mengelola limbah yang ada, sehingga hampir semua limbah yang dihasilkan di wilayah ini langsung dibuang ke saluran umum. Pembuangan limbah secara langsung tanpa pengolahan ini menyebabkan tingginya tingkat pencemaran lingkungan di sekitar lokasi industri.

Salah satu upaya untuk memecahkan masalah pengolahan limbah tersebut adalah menentukan teknologi IPAL yang cocok dalam mengatasi permasalahan di atas. Untuk menentukan teknologi IPAL ini, maka akan dilakukan ujicoba prototipe IPAL sebelum dilakukan penentuan teknologi IPAL yang tepat untuk di aplikasikan pada industri tersebut.

\section{TUJUAN DAN SASARAN}

Tujuan dari kegiatan ini ini adalah membuat prototipe Instalasi Pengolah Air Limbah (IPAL) untuk industri pengolahan ikan.

Sasaran yang ingin dicapai dari kegiatan ini adalah memperoleh suatu teknologi pengolah air limbah industri pengolahan ikan yang tepat untuk diterapkan di Kecamatan Muncar.

\section{METODOLOGI}

Metodologi pelaksanaan kegiatan ini ada 3 tahap yaitu :

\section{Tahap Survei}

Tahap kegiatan ini dilaksanakan di wilayah Kecamatan Muncar, Kabupaten Banyuwangi dengan melakukan observasi lapangan, pendataan industri dan kapasitas produknya serta koordinasi dengan pihak industri dan Pemda setempat.

\section{Tahap Pengumpulan Data}

Tahap ini merupakan pengumpulan data dengan melakukan survei :

a. Survei lokasi untuk mendapatkan datadata awal tentang :

- Peta wilayah Kota Muncar.

- Data jumlah industri.

- Sebaran lokasi industri. 
b. Survei kondisi industri untuk mendapatkan data-data :

- Data kapasitas industri.

- Data penggunaan sumber daya industri.

- Data tentangjumlah dan karakteristik limbah

c. Survai kondisi lingkungan sekitar industri untuk mendapatkan data-data :

- Dampak pembuangan limbah industri,

- $\quad$ Tingkat pencemaran yang telah terjadi,

- $\quad$ Dampak limbah terhadap kondisi sosial masyarakat sekitar

\section{Perancangan dan Implementasi Alat}

Tahap kegiatan ini adalah melakukan:

a. Analisis karakteristik limbah industri pengolahan ikan. Bertujuan untuk mengetahui karakteristik air limbah yang akan diolah sebagai dasar pemilihan teknologi IPAL.

b. Memilih teknologi pengolahan air limbah. Pemilihan teknologi didasarkan pada beberapa hal seperti karakteristik air limbah, kualitas air olahan yang diinginkan dan biaya operasional IPAL dan standar baku mutu limbah buangan yang berlaku.

c. Menetapkan dimensi-dimensi unit prototipe IPAL dan spesifikasi peralatannya.

d. Pembuatan gambar teknik. Gambar meliputi antara lain, gambar diagram proses dan gambar detail kontruksi.

e. Pembuatan prototipe berdasarkan gambar teknis.

f. Uji coba prototipe di lokasi penelitian di salah satu industri di Muncar.

\section{KARAKTERISTIKLIMBAHINDUSTRI PENGOLAHAN IKAN}

Industri pengolahan ikan di Muncar terdiri dari berbagai jenis industri pengolahan ikan, antara lain; industri pembuatan tepung ikan, industri pembuatan minyak ikan, industri pengalengan ikan, industri pembekuan ikan, industri petis ikan dll. Masing-masing kegiatan tersebut mempunyai proses produksi yang berbeda, sehingga kuantitas dan kualitas limbah yang dibuang juga akan berbeda tergantung dari jenis kegiatannya dan teknologi yang dipakai. Jenis industri bisa sama, teknologi juga dapat sama, tetapi belum tentu kuantitas dan kualitas limbah yang dibuang akan sama. Banyak faktor yang akan mempengaruhi kualitas limbah buangannya. Oleh karena itu, sebelum kita menentukan proses IPAL dan membuat disainnya, perlu dilakukan analisis dari karakteristik limbah yang ada berdasarkan hasil analisa laboratorium.

Hasil analisa karakteristik limbah industri di Muncar, berdasarkan "Laporan Verifikasi Kasus Pencemaran Kalimati Muncar-Banyuwangi"1) yang disusun oleh kantor Kementerian Lingkungan Hidup, tahun 2006 seperti terlihat pada Tabel 1, 2, dan 3 berikut: 
Tabel 1 : Hasil analisa air limbah industri pengolahan ikan ke 1

\begin{tabular}{|l|l|c|c|c|r|r|}
\hline No. & Parameter & $\begin{array}{c}\text { Baku Mutu Air } \\
\text { Limbah Kep. 51 } \\
\text { MENLH/10/1995 } \\
\text { (bersifat umum } \\
\text { bagi kegiatan } \\
\text { yang belum } \\
\text { ditetapkan } \\
\text { BMAL-nya) }\end{array}$ & $\begin{array}{c}\text { Baku Mutu } \\
\text { Air Limbah } \\
\text { Kep.Gub. } \\
\text { No. 45/2002. } \\
\text { (bagi kegiatan } \\
\text { pengalengan } \\
\text { dan tepung } \\
\text { ikan) }\end{array}$ & Satuan & \multicolumn{2}{|c|}{ Hasil Analisa } \\
\hline 1. & $\mathrm{pH}$ & $6-9$ & $6-9$ & $\mathrm{~A}$ & $\mathrm{~B}$ & \\
\hline 2. & $\mathrm{BOD}$ & 150 & 100 & $\mathrm{mg} / \mathrm{L}$ & 7.13 & 6.6 \\
\hline 3. & $\mathrm{COD}$ & 300 & 150 & $\mathrm{mg} / \mathrm{L}$ & 1011 & 14402 \\
\hline 4. & $\mathrm{TSS}$ & 400 & 30 & $\mathrm{mg} / \mathrm{L}$ & 268 & 1615 \\
\hline 5. & $\mathrm{M} \mathrm{dan} \mathrm{L}$ & 10 & 6.5 & $\mathrm{mg} / \mathrm{L}$ & 0.51 & 8.82 \\
\hline 6. & $\mathrm{NH} \mathrm{H}_{3} \mathrm{~N}$ & 5 & 5 & $\mathrm{mg} / \mathrm{L}$ & 0.002 & 0.106 \\
\hline 7. & Sulfida & 0.1 & 0.8 & $\mathrm{mg} / \mathrm{L}$ & 0.76 & 1.05 \\
\hline
\end{tabular}

A) outlet produksi ikan sardin

B) outlet produksi tepung ikan

Sumber : Laporan Verifikasi Kasus Pencemaran Kalimati Muncar - Banyuwangi, tahun 2006

Tabel 2 : Hasil analisa air limbah industri pengolahan ikan ke 2

\begin{tabular}{|l|l|c|c|c|c|}
\hline No. & Parameter & $\begin{array}{c}\text { Baku Mutu Air } \\
\text { Limbah } \\
\text { (Kep 51 } \\
\text { MENLH/10/1995) }\end{array}$ & $\begin{array}{c}\text { Baku Mutu Air } \\
\text { Limbah } \\
\text { (Kep Gub No. } \\
45 / 2002)\end{array}$ & Satuan & Hasil Analisa \\
\hline 1. & pH & $6-9$ & $6-9$ & $\mathrm{mg} / \mathrm{L}$ & 6.5 \\
\hline 2. & BOD & 150 & 100 & $\mathrm{mg} / \mathrm{L}$ & 2670 \\
\hline 3. & COD & 300 & 150 & $\mathrm{mg} / \mathrm{L}$ & 6245 \\
\hline 4. & TSS & 400 & 30 & $\mathrm{mg} / \mathrm{L}$ & 1280 \\
\hline 5. & M dan L & 10 & 6.5 & $\mathrm{mg} / \mathrm{L}$ & 5.79 \\
\hline
\end{tabular}

Sumber : Laporan Verifikasi Kasus Pencemaran

Kalimati Muncar - Banyuwangi, tahun 2006 
Tabel 3 : Hasil analisa kualitas air kalimati di Muncar

\begin{tabular}{|l|l|c|c|c|c|}
\hline No. & Parameter & $\begin{array}{c}\text { Baku Mutu Air } \\
\text { Limbah } \\
\text { (Kep 51 } \\
\text { MENLH/10/1995) }\end{array}$ & $\begin{array}{c}\text { Baku Mutu Air } \\
\text { Limbah } \\
\text { (Kep Gub No. } \\
45 / 2002)\end{array}$ & Satuan & Hasil Analisa \\
\hline 1. & $\mathrm{pH}$ & $6-9$ & $6-9$ & $\mathrm{mg} / \mathrm{L}$ & 6.5 \\
\hline 2. & BOD & 150 & 100 & $\mathrm{mg} / \mathrm{L}$ & 2670 \\
\hline 3. & COD & 300 & 150 & $\mathrm{mg} / \mathrm{L}$ & 6245 \\
\hline 4. & TSS & 400 & 30 & $\mathrm{mg} / \mathrm{L}$ & 1280 \\
\hline 5. & M dan L & 10 & 6.5 & $\mathrm{mg} / \mathrm{L}$ & 5.79 \\
\hline
\end{tabular}

Sumber : Laporan Verifikasi Kasus Pencemaran

Kalimati Muncar - Banyuwangi, tahun 2006

\section{TEKNOLOGI PROTOTIPE IPAL INDUSTRI PENGOLAHAN IKAN ${ }^{2)}$}

\subsection{Pemilihan Teknologi IPAL}

Dalam merencanakan teknologi prototype IPAL sama dengan merencanakan teknologi IPAL-nya. Sebab prototype tersebut akan diujicobakan terhadap limbah yang ditangani dan hasilnya nanti akan digunakan sebagai dasar perencanaan/ disain IPAL yang sebenarnya. Langkah-langkah yang perlu ditempuh dalam pengerjaan tersebut dimulai dari survai lapangan, analisa laboratorium, analisis data dan pemilihan teknologi (proses) yang akan digunakan. Jika langkah-langkah tersebut telah ditempuh baru dilakukan disain prototype IPAL yang direncanakan. Pekerjaan tidak hanya sampai di sini, pemilihan peralatan perlu dilakukan dengan tepat. Setiap unit alat (pompa, blower, bahan bangunan) mempunyai karakteristik yang berbeda dan harus disesuaikan dengan sifat-sifat limbah yang akan diolah serta kondisi lingkungannya.

Pemilihan proses, sistem dan spesifikasi alat yang tidak tepat atau disain IPAL yang salah akan menimbulkan berbagai persoalan di dalam IPAL itu sendiri, misalnya :

- biaya investasi, operasional maupun perawatannya akan menjadi mahal,

- sistem tidak dapat bekerja secara optimal,
- hasil olahan tidak seperti yang diinginkan,

- sulit dalam pengendalian/ operasional,

- Peralatan cepat rusak (korosi, panas, tidak awet dll).

Untuk menghindari hal-hal seperti tersebut di atas, maka dalam perencanaan suatu prototype IPAL harus dilakukan tahap demi tahap dan dilanjutkan dengan ujicoba di lapangan untuk mengolah limbah sebenarnya.

Berdasarkan analisis kualitas limbah berdasarkan hasil analisa laboratorium yang dilakukan oleh $\mathrm{KLH}$, maka teknologi prototype IPAL industri pengolahan ikan yang akan diterapkan adalah sebagai berikut.

\subsection{Teknologi Pengolahan Limbah}

Adanya berbagai permasalahan dalam mengatasi masalah pencemaran di wilayah Muncar seperti telah disebutkan diatas, maka diperlukan terobosan-terobosan agar dapat meminimalkan jumlah limbah maupun kadar polutan yang ada dan diperlukan teknologi pengelolaan limbah agar dapat memberikan hasil pengolahan yang optimal.

Berbagai upaya yang dapat dilakukan untuk mengurangi terjadinya pencemaran akibat kegiatan industri antara lain dengan 
pengembangan proses produksi bersih (nir limbah), minimisasi limbah, penggantian bahan berbahaya dan dengan teknologi pengolahan limbah (end of pipe). Teknologi pengolahan limbah meskipun digunakan sebagai pilihan penyelesaian terakhir dan dianggap kurang effisien, tetapi sampai saat ini teknologi ini masih sangat diperlukan.

Meskipun berbagai cara telah ditempuh untuk mencapai proses produksi bersih (nir limbah), tetapi teknologi ini belum dapat diterapkan pada semua sektor industri dan masih sedikit sekali teknisi/ konsultan yang menguasai teknologi ini. Jika langkah-langkah minimisasi limbah telah ditempuh tetapi limbah masih dihasilkan, maka langkah pengolahan harus dilakukan. Tujuan dari proses pengolahan dapat bermacam-macam, antara lain dapat untuk recycle kembali, reuses, atau untuk dibuang ke saluran umum (end of pipe).

Dalam bahasan ini akan disampaikan teknologi pengolahan limbah industri ikan, tentunya hal ini dilakukan setelah adanya upaya peningkatan / perbaikan proses produksi dan upaya minimalisasi limbah lainnya.

\section{Proses IPAL Secara Umum}

Pengolahan air limbah bertujuan untuk menghilangkan parameter pencemar yang ada di dalam air limbah sampai batas yang diperbolehkan untuk dibuang ke badan air sesuai dengan syarat baku mutu yang diijinkan atau sampai memenuhi kualitas tertentu untuk dimanfaatkan kembali. Pengolahan air limbah secara garis besar dapat dibagi yakni pemisahan padatan tersuspensi (solidliquid separation), pemisahan senyawa koloid, serta penghilangan senyawa polutan terlarut. Ditinjau dari jenis prosesnya dapat dikelompokkan : proses pengolahan secara fisika, proses secara kimia, proses secara fisika-kimia serta proses pengolahan secara biologis.

Penerapan masing-masing metode tergantung pada karakteristik limbahnya dan kualitas hasil yang diinginkan. Klasifikasi jenis proses pengolahan untuk menghilangkan senyawa pencemar dalam air limbah dapat dilihat pada Tabel 4.

Ditinjau dari urutannya proses pengolahan air limbah dapat dibagi menjadi tiga jenis pengolahan, yakni :

Tabel 4 : Klasifikasi proses pengolahan air limbah menurut jenis kontaminannya

\begin{tabular}{|l|l|l|}
\hline KONTAMINAN & SISTEM PENGOLAHAN & KLASIFIKASI \\
\hline \multirow{5}{*}{ Padatan Tersuspensi } & Screening dan communition & $\mathrm{F}$ \\
\cline { 2 - 3 } & Sedimentasi & $\mathrm{F}$ \\
\cline { 2 - 3 } & Flotasi & $\mathrm{F}$ \\
\cline { 2 - 3 } & Filtrasi & $\mathrm{F}$ \\
\cline { 2 - 3 } & Koagulasi/sedimentasi & $\mathrm{K} / \mathrm{F}$ \\
\cline { 2 - 3 } & Land treatment & $\mathrm{F}$ \\
\hline Biodegradable Organics & Lumpur aktif & $\mathrm{B}$ \\
\cline { 2 - 3 } & Trickling filters & $\mathrm{B}$ \\
\cline { 2 - 3 } & Rotating biological contactors & $\mathrm{B}$ \\
\cline { 2 - 3 } & Aerated lagoons (kolam aerasi) & $\mathrm{B}$ \\
\cline { 2 - 3 } & Saringan pasir & $\mathrm{F} / \mathrm{B}$ \\
\cline { 2 - 3 } & Land treatment & $\mathrm{B} / \mathrm{K} / \mathrm{F}$ \\
\hline
\end{tabular}




\begin{tabular}{|c|c|c|}
\hline \multirow[t]{3}{*}{ Pathogens } & Khlorinasi & $\mathrm{K}$ \\
\hline & Ozonisasi & $\mathrm{K}$ \\
\hline & Land treatment & $\mathrm{F}$ \\
\hline \multirow[t]{6}{*}{ Nitrogen } & $\begin{array}{l}\text { Suspended-growth nitrification and } \\
\text { denitrification }\end{array}$ & $B$ \\
\hline & $\begin{array}{l}\text { Fixed-film nitrification and } \\
\text { denitrification }\end{array}$ & $\mathrm{B}$ \\
\hline & Ammonia stripping & $\mathrm{K} / \mathrm{F}$ \\
\hline & Ion Exchange & $\mathrm{K}$ \\
\hline & Breakpoint khlorinasi & $\mathrm{K}$ \\
\hline & Land treatment & $\mathrm{B} / \mathrm{K} / \mathrm{F}$ \\
\hline \multirow[t]{4}{*}{ Phospor } & Koagulasi garam logam/sedimentasi & $\mathrm{K} / \mathrm{F}$ \\
\hline & Koagulasi kapur/sedimentasi & $\mathrm{K} / \mathrm{F}$ \\
\hline & $\begin{array}{l}\text { Biological/Chemical phosphorus } \\
\text { removal }\end{array}$ & $\mathrm{B} / \mathrm{K}$ \\
\hline & Land treatment & $\mathrm{K} / \mathrm{F}$ \\
\hline \multirow[t]{3}{*}{ Refractory Organics } & Adsorpsi karbon & $\mathrm{F}$ \\
\hline & Tertiary ozonation & $\mathrm{K}$ \\
\hline & Sistem land treatment & $\mathrm{F}$ \\
\hline \multirow[t]{3}{*}{ Logam Berat } & Pengendapan kimia & $\mathrm{K}$ \\
\hline & Ion Exchange & $\mathrm{K}$ \\
\hline & Land treatment & $\mathrm{F}$ \\
\hline \multirow[t]{3}{*}{ Padatan Inorganik Terlarut } & Ion Exchange & $\mathrm{K}$ \\
\hline & Reverse Osmosis & $\mathrm{F}$ \\
\hline & Elektrodialisis & $\mathrm{K}$ \\
\hline
\end{tabular}

\section{a. Pengolahan secara fisika}

Pada umumnya, sebelum dilakukan pengolahan lanjutan terhadap air buangan, diinginkan agar bahan-bahan tersuspensi berukuran besar dan yang mudah mengendap atau bahan-bahan yang terapung disisihkan terlebih dahulu. Penyaringan (screening) merupakan cara yang efisien dan murah untuk menyisihkan bahan tersuspensi yang berukuran besar. Bahan tersuspensi yang mudah mengendap dapat disisihkan secara mudah dengan proses pengendapan. Parameter desain yang utama untuk proses pengendapan ini adalah kecepatan mengendap partikel dan waktu detensi hidrolis di dalam bak pengendap ${ }^{(3)}$.

\section{b. pengolahan secara kimia}

Pengolahan air buangan secara kimia biasanya dilakukan untuk menghilangkan partikel-partikel yang tidak mudah mengendap (koloid), logam-logam berat, senyawa fosfor, dan zat organik beracun; dengan membubuhkan bahan kimia tertentu yang diperlukan. Penyisihan bahan-bahan tersebut pada prinsipnya berlangsung melalui perubahan sifat bahan-bahan tersebut, yaitu dari tak dapat diendapkan menjadi mudah diendapkan (flokulasi-koagulasi), baik 
dengan atau tanpa reaksi oksidasi-reduksi, dan juga berlangsung sebagai hasil reaksi oksidasi3).

\section{c. Pengolahan secara biologi \\ Semua air buangan yang} biodegradable dapat diolah secara biologi. Sebagai pengolahan sekunder, pengolahan secara biologi dipandang sebagai pengolahan yang paling murah dan efisien. Dalam beberapa dasawarsa telah berkembang berbagai metode pengolahan biologi dengan segala modifikasinya ${ }^{3)}$.

\section{Pengolahan Air Limbah Secara Fisika dan Kimia ${ }^{3}$}

a. Proses Screening (Penyaringan)

Di dalam proses pengolahan air limbah, screening (saringan) atau saringan dilakukan pada tahap paling awal. Saringan untuk penggunaan umum (general porpose screen) dapat digunakan untuk memisahkan bermacam-macam benda padat yang ada di dalam air limbah, misalnya kertas, plastik, kain, kayu dan benda dari metal serta lainnya. Benda-benda tersebut jika tidak dipisahkan dapat menyebabkan kerusakan pada sistem pemompaan dan unit peralatan pemisah lumpur misalnya weir, block valve, nozle, saluran serta perpipaan. Hal tersebut dapat menimbulkan masalah yang serius terhadap operasional maupun pemeliharaan peralatan. Saringan yang halus kadang-kadang dapat juga digunakan untuk memisahkan padatan tersuspensi.

\section{b. Unit Pemisah Pasir (Grit Removal)}

Di dalam proses pengolahan air limbah pasir, kerikil halus, dan juga bendabenda lain misalnya kepingan logam, pecahan kaca, tulang, dan lain lain yang mana tidak dapat membusuk, harus dipisahkan terlebih dahulu. Hal ini dilakukan untuk :

- Melindungi kerusakan pada peralatan mekanik seperti pompa, flow meter dll, agar tidak terjadi abrasi atau ikan ini merupakan limbah industri makanan, maka $\mathrm{pH}$ dari limbah ini tidak akan terlalu ekstrim (asam/basa). Karena kondisi yang telah relatip netral ini, maka tidak diperlukan lagi adanya unit/ alat untuk pengontrolan $\mathrm{pH}$ limbah.

\section{d. Proses Koagulasi - Flokulasi}

Koagulasi adalah proses destabilisasi partikel koloid dengan cara penambahan senyawa kimia yang disebut koagulan. Koloid mempunyai ukuran tertentu sehingga gaya tarik menarik antara partikel lebih kecil dari pada gaya tolak menolak akibat muatan listrik. Pada kondisi stabil ini penggumpalan partikel tidak terjadi dan gerakan Brown menyebabkan partikel tetap berada sebagai suspensi. Melalui proses koagulasi terjadi destabilisasi, sehingga partikel-partikel koloid bersatu dan menjadi besar. Dengan demikian partikel-partikel koloid yang pada awalnya sukar dipisahkan dari air, setelah proses koagulasi akan menjadi kumpulan partikel yang lebih besar sehingga mudah dipisahkan dengan cara sedimentasi, filtrasi atau proses pemisahan lainnya yang lebih mudah.

Koagulasi adalah proses destabilisasi koloid dengan penambahan senyawa kimia yang disebut zat koagulan. Flokulasi adalah proses penggumpalan (agglomeration) dari koloid yang tidak stabil menjadi gumpalan partikel halus (mikro-flok), dan selanjutnya menjadi gumpalan patikel yang lebih besar dan dapat diendapkan dengan cepat. Senyawa kimia lain yang diberikan agar pembentukan flok menjadi lebih cepat atau lebih stabil dinamakan flokulan atau zat pembantu flokulasi (flokulan aid).

Di dalam sistem pengolahan air limbah dengan penambahan bahan kimia proses koagulasi sangat diperlukan untuk proses awal. Partikel-partikel yang sangat halus maupun partikel koloid yang terdapat dalam air limbah sulit sekali mengendap. Oleh karena itu perlu proses koagulasi yaitu penambahan bahan kimia agar partikel-partikel yang sukar mengendap 
tadi menggumpal menjadi besar dan berat sehingga kecepatan pengendapannya lebih besar.

\section{e. Tangki Pencampur \\ Tangki pencampur dilengkapi} dengan alat pengaduk/agitator agar bahan kimia (koagulan) yang dibubuhkan dapat bercampur dengan air baku secara cepat dan merata. Oleh karena kecepatan hidrolisa koagulan dalam air besar maka diperlukan pembentukan flok-flok halus dari koloid hidroksida yang merata dan secepat mungkin sehingga dapat bereaksi dengan partikelpartikel kotoran membentuk flok yang lebih besar dan stabil. Untuk itu diperlukan pengadukan yang cepat.

\section{f. Flokulator}

Fungsi flokulator adalah untuk pembentukan flok-flok agar menjadi besar dan stabil sehingga dapat diendapkan dengan mudah atau disaring. Untuk proses pengendapan dan penyaringan maka partikel-partikel kotoran halus maupun koloid yang ada dalam air baku harus digumpalkan menjadi flok-flok yang cukup besar dan kuat untuk dapat diendapkan atau disaring.

Flokulator pada hakekatnya adalah kombinasi antara pencampuran dan pengadukan sehingga flok-flok halus yang terbentuk pada bak pencampur cepat akan saling bertumbukan dengan partikel-partikel kotoran atau flok-flok yang lain sehingga terjadi gumpalan gumpalan flok yang besar dan stabil.

\section{g. Sedimentasi atau Pengendapan}

Sedimentasi adalah suatu unit operasi untuk menghilangkan materi tersuspensi atau flok kimia secara gravitasi. Proses sedimentasi pada pengolahan air limbah umumnya untuk menghilangkan padatan tersuspensi sebelum dilakukan proses pengolahan selanjutnya. Gumpalan padatan yang terbentuk pada proses koagulasi masih berukuran kecil. Gumpalan-gumpalan kecil ini akan terus saling bergabung menjadi gumpalan yang lebih besar dalam proses flokulasi. Dengan terbentuknya gumpalangumpalan besar, maka beratnya akan bertambah, sehingga karena gaya beratnya gumpalan-gumpalan tersebut akan bergerak ke bawah dan mengendap pada bagian dasar tangki sedimentasi.

Bak sedimentasi dapat berbentuk segi empat atau lingkaran. Pada bak ini aliran air limbah sangat tenang untuk memberi kesempatan padatan/suspensi untuk mengendap. Kriteria-kriteria yang diperlukan untuk menentukan ukuran bak sedimentasi adalah: surface loading (beban permukaan), kedalaman bak dan waktu tinggal. Waktu tinggal mempunyai satuan jam, cara perhitungannya adalah volume tangki dibagi dengan laju alir per hari. Beban permukaan sama dengan laju alir (debit volume) rata-rata per hari dibagi luas permukaan bak, satuannya $\mathrm{m}^{3}$ per meter persegi per hari seperti pada rumus berikut ini ${ }^{3)}$.

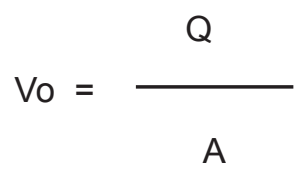

Keterangan :

$\begin{aligned} \text { Vo } & =\begin{array}{l}\text { laju limpahan/beban permukaan } \\ \left(\mathrm{m}^{3} / \mathrm{m}^{2} \text { hari }\right)\end{array} \\ \mathbf{Q} & =\begin{array}{l}\text { aliran rata-rata harian, } \\ \mathrm{m}^{3} \text { per hari }\end{array} \\ A & =\text { total luas permukaan }\left(\mathrm{m}^{2}\right)\end{aligned}$

h. Pengeringan / Pengolahan Lumpur

Lumpur yang dihasilkan dari proses sedimentasi diolah lebih lanjut untuk mengurangi sebanyak mungkin air yang masih terkandung didalamnya. Proses pengolahan lumpur yang bertujuan mengurangi kadar air tersebut sering disebut dengan pengeringan lumpur. Ada empat cara proses pengurangan kadar air, yaitu secara alamiah, dengan tekanan (pengepresan), dengan gaya sentrifugal dan dengan 
pemanasan.

Pengeringan secara alamiah dilakukan dengan mengalirkan atau memompa lumpur endapan ke sebuah kolam pengering (drying bed) yang mempunyai luas permukaan yang besar. Proses pengeringan berjalan dengan alamiah, yaitu dengan panas matahari dan angin yang bergerak di atas kolam pengering lumpur tersebut. Cara pengeringan seperti ini tentu saja sangat bergantung dari cuaca dan akan bermasalah bila terjadi hujan. Bila lumpur tidak mengandung bahan yang berbahaya, maka kolam pengering lumpur dapat hanya berupa galian tanah biasa, sehingga sebagian air akan meresap ke dalam tanah dibawahnya. Contoh pengeringan lumpur antara lain pengeringan lumpur dengan cara tekanan (pengepresan) dan proses pengeringan lumpur dengan gaya centrifugal (centrifuge).

i. Proses Biologis untuk Pengolahan Air Limbah ${ }^{(4)}$.

Di dalam proses pengolahan air limbah khususnya yang mengandung polutan senyawa organik, teknologi yang digunakan sebagian besar menggunakan aktifitas mikro-organisme untuk menguraikan senyawa polutan organik tersebut. Proses pengolahan air limbah dengan aktifitas mikroorganisme biasa disebut dengan "Proses Biologis".

Proses pengolahan air limbah secara biologis tersebut dapat dilakukan pada kondisi aerobik (dengan udara), kondisi anaerobik (tanpa udara) atau kombinasi anaerobik dan aerobik. Proses biologis aeorobik biasanya digunakan untuk pengolahan air limbah dengan beban BOD yang tidak terlalu besar, sedangkan proses biologis anaerobik digunakan untuk pengolahan air limbah dengan beban BOD yang sangat tinggi.

Menurut Bitton (1994) proses pengolahan air limbah secara bilogis dapat dibagi menjadi tiga yakni proses biologis dengan biakan tersuspensi (suspended culture), proses biologis dengan biakan melekat (attached culture) dan proses pengolahan dengan sistem lagoon atau kolam (Gambar 1). Proses biologis dengan biakan tersuspensi adalah sistem pengolahan dengan menggunakan aktifitas mikroorganisme untuk menguraikan senyawa polutan yang ada dalam air dan mikroorganime yang digunakan dibiakkan secara tersuspesi di dalam suatu reaktor. Beberapa contoh proses pengolahan dengan sistem ini antara lain : proses lumpur aktif standar/ konvesional (standard activated sludge), step aeration, contact stabilization, extended aeration, oxidation ditch (kolam oksidasi sistem parit) dan lainnya.

Proses biologis dengan biakan melekat yakni proses pengolahan limbah dimana mikro-organisme yang digunakan dibiakkan pada suatu media sehingga mikroorganisme tersebut melekat pada permukaan media. Proses ini disebut juga dengan proses film mikrobiologis atau proses biofilm.

Beberapa contoh teknologi pengolahan air limbah dengan cara ini antara lain: trickling filter, rotating biological contactor, contact aeration/oxidation dan lainnnya.

Proses pengolahan air limbah secara biologis dengan lagoon atau kolam adalah dengan menampung air limbah pada suatu kolam yang luas dengan waktu tinggal yang cukup lama sehingga dengan aktifitas mikro-organisme yang tumbuh secara alami, senyawa polutan yang ada dalam air akan terurai. Untuk mempercepat proses penguraian senyawa polutan atau memperpendek waktu tin ggal dapat juga dilakukan proses aerasi. Salah satu contoh proses pengolahan air limbah dengan cara ini adalah kolam aerasi atau kolam stabilisasi (stabilization pond). Proses dengan sistem lagoon tersebut kadangkadang dikategorikan sebagai proses biologis dengan biakan tersuspensi. Karakteristik pengolahan, parameter perencanaan serta efisiensi pengolahan untuk tiap jenis proses dapat dilihat pada Tabel 5 dan Tabel 6 .

Pemilihan teknologi pengolahan air limbah harus mempertimbangkan beberapa hal yakni antara lain jumlah air limbah 


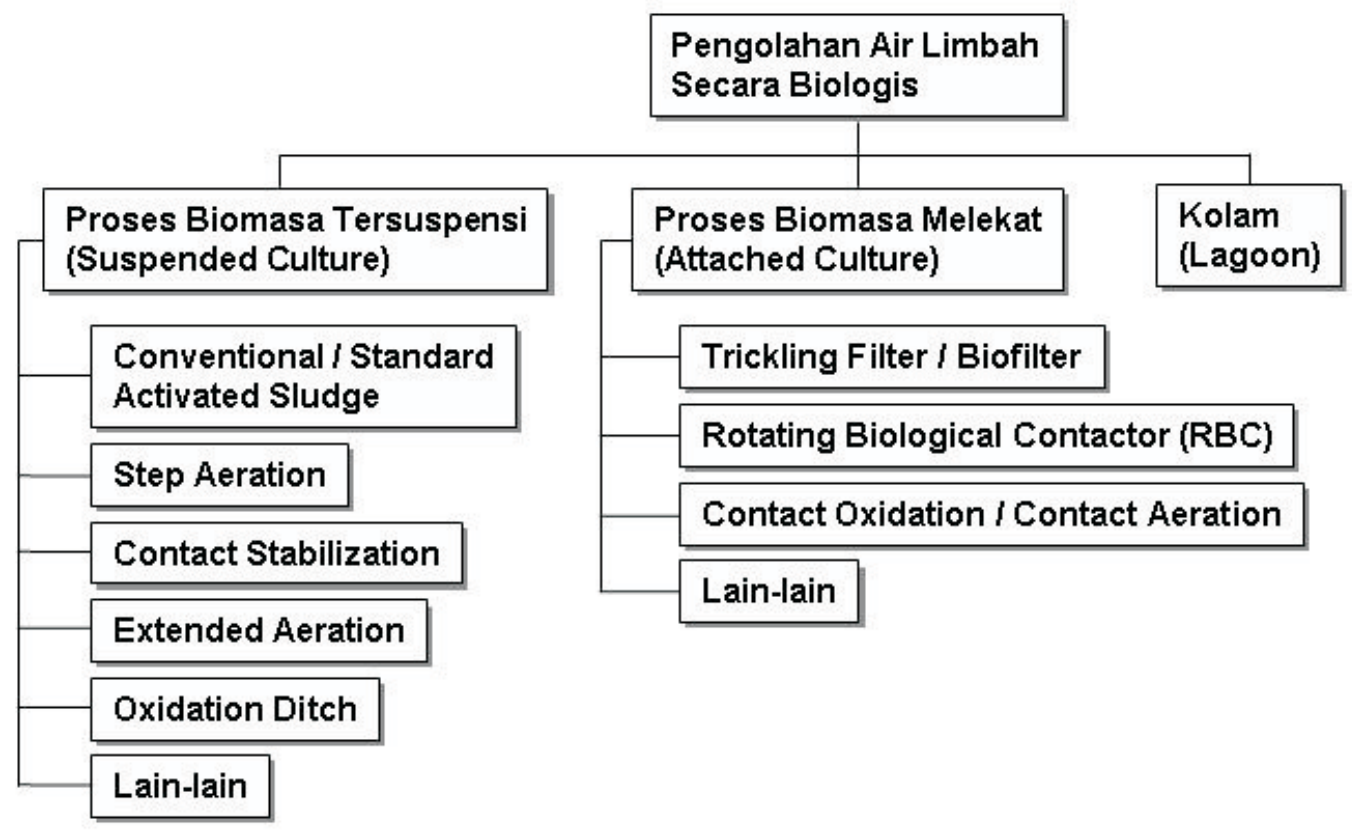

Gambar 1 : Proses pengolahan air limbah secara biologis aerobik.

yang akan diolah, kualitas air hasil olahan yang diharapkan, kemudahan dalam hal pengelolaan, ketersediaan lahan dan sumber energi, serta biaya operasi dan perawatan diupayakan serendah mungkin

Setiap jenis teknologi pengolahan air limbah mempunyai keunggulan dan kekurangannya masing-masing, oleh karena itu dalam hal pemilihan jenis teknologi tersebut perlu diperhatikan aspek teknis, aspek ekonomis dan aspek lingkungan, serta sumber daya manusia yang akan mengelola fasilitas tersebut.

\section{PROSES PENGOLAHAN PROTOTIPE IPAL INDUSTRI PENGOLAHAN IKAN}

Proses pengolahan prototipe IPAL untuk industri pengolahan ikan terlihat pada gambar 2 dan 3. Air limbah dialirkan ke alat pengolahan melalui lubang pemasukan (inlet) masuk ke ruang (bak) pengendapan awal. Selanjutnya air limpasan dari bak pengendapan awal air dialirkan ke zona anaerob. Zona anaerob tersebut terdiri dari dua ruangan yang diisi dengan media dari bahan plastik sarang tawon untuk pembiakan mikroba. Pada zona anaerob pertama air limbah mengalir dengan arah aliran dari atas ke bawah, sedangkan pada zona anaerob ke dua air limbah mengalir dengan arah aliran dari bawah ke atas. Selanjutnya air limpasan 
Tabel 5 : Karakterisitik operasional proses pengolahan air limbah dengan proses biologis

\begin{tabular}{|c|c|c|c|}
\hline \multicolumn{2}{|c|}{ JENIS PROSES } & \multirow{2}{*}{\begin{tabular}{|c} 
EFISIENSI \\
PENGHILANGAN \\
BOD $(\%)$ \\
$85-95$
\end{tabular}} & \multirow{2}{*}{\begin{tabular}{|l|} 
KETERANGAN \\
-
\end{tabular}} \\
\hline \multirow{8}{*}{$\begin{array}{l}\text { PPROSES } \\
\text { BIOMASA } \\
\text { TERSUSPENSI }\end{array}$} & $\begin{array}{l}\text { Lumpur Aktif } \\
\text { Standar }\end{array}$ & & \\
\hline & Step Aeration & $85-95$ & $\begin{array}{l}\text { Digunakan untuk beban } \\
\text { pengolahan yang besar. }\end{array}$ \\
\hline & Modified Aeration & $60-75$ & $\begin{array}{l}\text { Untuk pengolahan dengan } \\
\text { kualitas air olahan sedang. }\end{array}$ \\
\hline & $\begin{array}{l}\text { Contact } \\
\text { Stabilization }\end{array}$ & $80-90$ & $\begin{array}{l}\text { Digunakan untuk } \\
\text { pengolahan paket. Untuk } \\
\text { mereduksi ekses lumpur. }\end{array}$ \\
\hline & High Rate Aeration & $75-90$ & $\begin{array}{l}\text { Untuk pengolahan } \\
\text { paket, bak aerasi dan } \\
\text { bak pengendap akhir } \\
\text { merupakan satu paket. } \\
\text { Memerlukan area yang } \\
\text { kecil. } \\
\end{array}$ \\
\hline & $\begin{array}{l}\text { Pure Oxygen } \\
\text { Process }\end{array}$ & $85-95$ & $\begin{array}{l}\text { Untuk pengolahan air } \\
\text { limbah yang sulit diuraikan } \\
\text { secara bilogis. Luas area } \\
\text { yang dibutuhkan kecil. }\end{array}$ \\
\hline & Oxidation Ditch & $75-95$ & $\begin{array}{l}\text { Konstruksinya mudah, } \\
\text { tetapi memerlukan area } \\
\text { yang luas. }\end{array}$ \\
\hline & Trickling Filter & $80-95$ & $\begin{array}{l}\text { Sering timbul lalat dan bau } \\
\text { Proses operasinya mudah. }\end{array}$ \\
\hline \multirow[t]{3}{*}{$\begin{array}{l}\text { PROSES } \\
\text { BIOMASA } \\
\text { MELEKAT }\end{array}$} & $\begin{array}{l}\text { Rotating Biological } \\
\text { Contactor }\end{array}$ & $80-95$ & $\begin{array}{l}\text { Konsumsi energi rendah, } \\
\text { produksi lumpur kecil. } \\
\text { Tidak memerlukan proses } \\
\text { aerasi. }\end{array}$ \\
\hline & $\begin{array}{l}\text { Contact Aeration } \\
\text { Process }\end{array}$ & $80-95$ & $\begin{array}{l}\text { Memungkinkan untuk } \\
\text { penghilangan nitrogen dan } \\
\text { phospor. }\end{array}$ \\
\hline & Biofilter Unaerobic & $65-85$ & $\begin{array}{l}\text { memerlukan waktu tinggal } \\
\text { yang lama, lumpur yang } \\
\text { terjadi kecil. }\end{array}$ \\
\hline LAGOON & Kolam stabilisai & $60-80$ & $\begin{array}{l}\text { memerlukan waktu tinggal } \\
\text { yang cukup lama, dan area } \\
\text { yang dibutukkan sangat } \\
\text { luas }\end{array}$ \\
\hline
\end{tabular}


Tabel 6 : Parameter perencanaan proses pengolahan air limbah dengan proses biologis aerobik.

\begin{tabular}{|c|c|c|c|c|c|c|c|}
\hline \multicolumn{2}{|c|}{ JENIS PROSES } & \multicolumn{2}{|c|}{$\begin{array}{l}\text { BEBAN BOD } \\
\text { BOD kg/kg SS.d } \\
\text { BOD kg/m .d }\end{array}$} & \multirow[t]{2}{*}{$\begin{array}{l}\text { MLSS } \\
(\mathrm{mg} / \mathrm{lt})\end{array}$} & \multirow[t]{2}{*}{$\mathrm{QA} / \mathrm{Q}$} & \multirow[t]{2}{*}{$\mathrm{T}$ (Jam) } & \multirow[t]{2}{*}{$\begin{array}{l}\text { EFISIENSI } \\
\text { PENGHI- } \\
\text { LANGAN } \\
\text { BOD }(\%)\end{array}$} \\
\hline PROSES & Lumpur & & & & & & \\
\hline \multirow{9}{*}{$\begin{array}{l}\text { BIOMASA } \\
\text { TER } \\
\text { SUSPENSI }\end{array}$} & $\begin{array}{l}\text { Aktif } \\
\text { Standar }\end{array}$ & $0,2-0,4$ & $0,3-0,8$ & $1500-2000$ & $3-7$ & $6-8$ & $85-95$ \\
\hline & $\begin{array}{l}\text { Step } \\
\text { Aeration }\end{array}$ & $0,2-0,4$ & $0,4-1,4$ & $1000-1500$ & $3-7$ & $4-6$ & $85-95$ \\
\hline & $\begin{array}{l}\text { Modified } \\
\text { Aeration }\end{array}$ & $1,5-3,0$ & $0,6-2,4$ & $400-800$ & $2-2,5$ & $1,5-30$ & $60-75$ \\
\hline & $\begin{array}{l}\text { Contact } \\
\text { Stabilization }\end{array}$ & 0,2 & $0,8-1,4$ & $2000-8000$ & $>12$ & $>5$ & $80-90$ \\
\hline & $\begin{array}{l}\text { High Rate } \\
\text { Aeration }\end{array}$ & $0,2-0,4$ & $0,6-2,4$ & $3000-6000$ & $5-8$ & $2-3$ & $75-90$ \\
\hline & Pure & & & & & & \\
\hline & $\begin{array}{l}\text { Oxygen } \\
\text { Process }\end{array}$ & $0,3-0,4$ & $1,0-2,0$ & $3000-4000$ & - & $1-3$ & $85-95$ \\
\hline & $\begin{array}{l}\text { Oxidation } \\
\text { Ditch } \\
\end{array}$ & $\begin{array}{l}0,03- \\
0,04 \\
\end{array}$ & $0,1-0,2$ & $3000-4000$ & - & $24-48$ & $75-95$ \\
\hline & $\begin{array}{l}\text { Extended } \\
\text { Aeration }\end{array}$ & $\begin{array}{l}0,03- \\
0,05 \\
\end{array}$ & $0,15-0,25$ & $3000-6000$ & $>15$ & $16-24$ & $75-95$ \\
\hline \multirow{6}{*}{$\begin{array}{l}\text { PROSES } \\
\text { BIOMASA } \\
\text { MELEKAT }\end{array}$} & $\begin{array}{l}\text { Trickling } \\
\text { Filter }\end{array}$ & - & $0,08-0,4$ & - & - & - & $80-95$ \\
\hline & $\begin{array}{l}\text { Rotating } \\
\text { Biological }\end{array}$ & & & & & & \\
\hline & Contactor & - & $0,01-0,3$ & - & - & - & $80-95$ \\
\hline & $\begin{array}{l}\text { Contact } \\
\text { Aeration }\end{array}$ & & & & & & \\
\hline & Process & - & - & - & - & - & $80-95$ \\
\hline & $\begin{array}{l}\text { B i ofilter } \\
\text { Unaerobic }\end{array}$ & - & - & - & - & - & $65-85$ \\
\hline
\end{tabular}

CATATAN : $Q=$ Debit Air Limbah $\left(M^{3} /\right.$ day $)$

$\mathrm{Qr}=$ Return Sludge $\left(\mathrm{M}^{3} /\right.$ day $)$

$\mathrm{QA}=$ Laju Alir Suplai Udara (M3/day) 
dari zona anaerob ke dua mengalir ke zona aerob melalui lubang (weir).

Di dalam zona aerob tersebut air limbah dialirkan ke unggun media plastik sarang tawon dengan arah aliran dari bawah ke atas, sambil dihembus dengan udara. Air limbah dari zona aerob masuk ke bak pengendapan akhir melalui saluran yang ada di bagian bawah.

Air limbah yang ada di dalam bak pengendapan akhir tersebut disirkulasikan ke zona anaerob pertama, sedangkan air limpasan dari bak pengendapan akhir tersebut merupakan air hasil olahan dan keluar melalui lubang pengeluaran, selanjutnya air limpasan dari bak ini dibuang ke saluran umum.

Setelah proses berjalan selama dua sampai empat minggu pada permukaan media sarang tawon akan tumbuh lapisan mikro-organisme, yang akan menguraikan senyawa polutan yang ada dalam air limbah.

Gambar prototipe sistem pengolahan air limbah dengan kombinasi proses biofilter anaerob-aerob mempunyai kapasitas olah 5 $\mathrm{m}^{3}$ perhari ditunjukkan seperti pada Gambar 4.

\subsection{Pengolahan Secara Fisika - Kimia}

Proses pengolahan prototipe IPAL secara fisika kimia dilakukan berdasarkan tahapan berikut ini :

1. Limbah segar yang dihasilkan dari proses produksi pengolahan ikan disalurkan ke bak penampungan yang di depannya dilengkapi dengan saringan untuk memisahkan padatan yang berukuran besar.

2. Setelah melalui saringan, limbah dialirkan ke bak pengumpul. Di dalam bak ini, padatan yang berat (pasir, tanah) diendapkan di bagian dasar.

3. Limbah yang digunakan sebagai umpan ujicoba (prototipe IPAL)

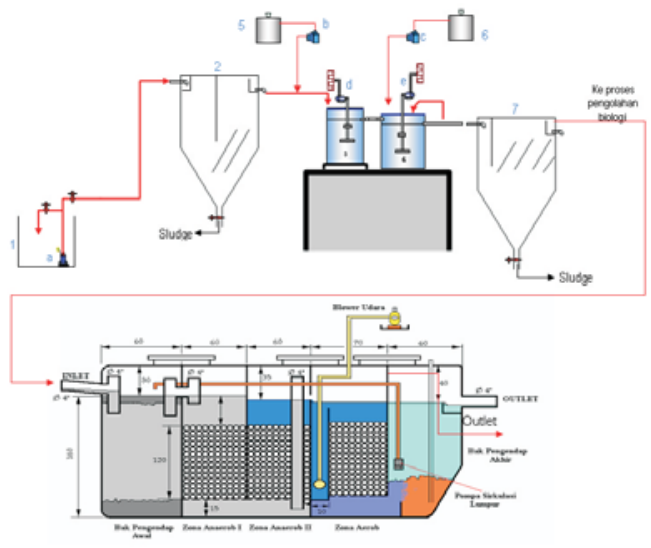

Gambar 2 : Diagram alir prototipe IPAL industri pengolahan ikan

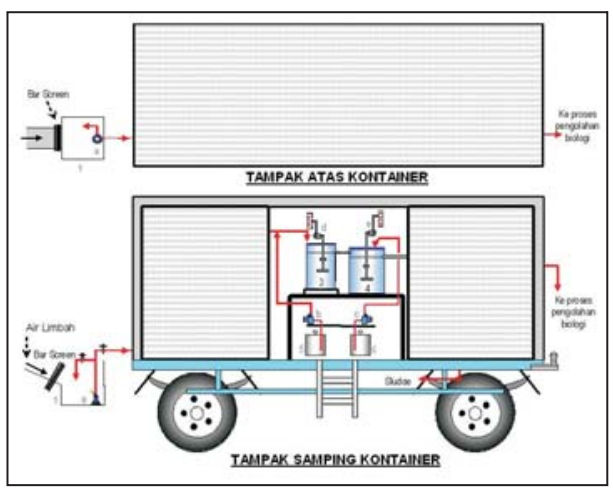

Gambar 3 : Tampak atas dan samping kontainer pengolah fisika-kimia

diambil dari dalam bak ini dengan cara pemompaan.

4. Dalam waktu periode tertentu (1 minggu) kondisi bak harus di cek untuk melihat jumlah padatan yang telah terkumpul di dalam bak. Bersihkan bak dari Lumpur dan padatan lainnya.

5. Umpan limbah pertama kali masuk ke tangki pemisah minyak, yang berfungsi juga sebagai tangki pengendap jika 


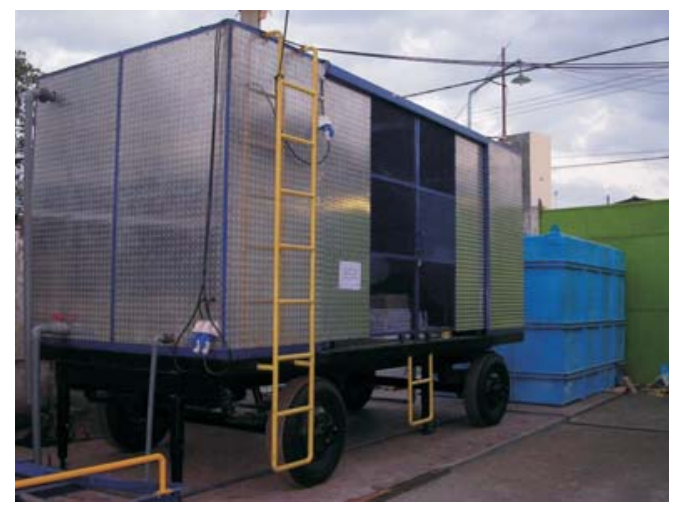

Gambar 4. Prototipe IPAL dengan unit proses fisika-kimia dengan kombinasi proses biofilter anaerob-aerob

masih ada padatan yang terikut dalam aliran feed.

6. Oli akan terkumpul di bagian atas tangki pemisah minyak, dalam dalam periode tertentu (jika lapisan minyak telah tebal) minyak dapat dialirkan keluar tangki dengan menutup kran over flow tangki ini.

7. Setelah melalui tangki pemisah minyak ini, limbah akan mengalir secara gravitasi ke reaktor koagulasi-flokulasi. Disini akan dilakukan proses koagulasiflokulasi dengan menggunakan bahan kimia (alum/tawas dan kuriflok). Bahan kimia koagulan lain seperti PAC, Zeta ace, dan bahan lainnya juga dapat digunakan, tergantung dari kondisi limbah.

8. Pengaturan debit limbah yang akan diolah dapat dilakukan dengan mengatur posisi ball valve yang terdapat di pompa feed.

9. Kebutuhan bahan kimia untuk proses koagulasi-flokulasi diatur dengan menggunakan dua buah pompa dosing. Jumlah kebutuhan bahan koagulan dan flokulan ditentukan berdasarkan dari hasil jar test yang telah dilakukan. Sedangkan untuk meningkatkan proses reaksi agar dapat terbentuk flok dengan ukuran besar serta kuat sehingga proses sedimentasi dapat terjadi dengan sempurna di reaktor koagulasi dan flokulasi dilengkapi dengan agitator.

10. Setelah melalui proses koagulasiflokulasi, limbah dialirkan ke bak pengendap. Tangki bak pengendap ini berbetuk kerucut di bagian bawahnya dan dilengkapi dengan agitator. Agitator yang ada secara periodik dihidupkan agar flok yang ada dapat terkumpul di dasar tangki dan dapat dengan mudah untuk dipisahkan/ dikeluarkan dari dalam tangki. Sedangkan air yang sudah bersih akan mengalir secara over flow dari bak pengendap untuk selanjutnya diproses secara biologi dengan biofilter.

\subsection{Pengolahan Secara Biologi}

Untuk melakukan start-up biofilter, langkah pertama yang harus dilakukan adalah melakukan pengecekan sistem prototipe IPAL secara keseluruhan. Pengecekan sistem meliputi pengecekan kebocoran bak, pengecekan perpipaan dalam IPAL, pengecekan sistem kelistrikan, pengecekan pompa-pompa, pengecekan sistem suplai udara ke reaktor aerobik dan pengecekan bak-bak pengumpul. Setelah yakin kalau sistem biofilter sudah sempurna, selanjutnya

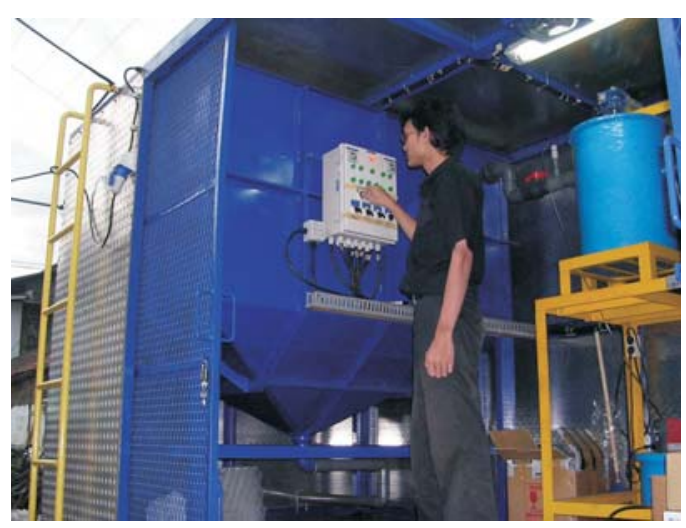

Gambar 5. Mengoperasikan tangki pemisah minyak dan pengendap awal 
dilakukan pengisian biofilter dengan urutan sebagai berikut:

1. Isi semua bak di biofilter dengan air limbah secara bersamaan. Pengisian IPAL diusahakan merata jangan sampai sebagian penuh, bagian yang lain masih kosong. Pada posisi penuh dengan air limbah, cek semua dinding bak biofilter apakah ada kebocoran atau tidak.

2. Setelah IPAL penuh selanjutnya blower pada bak aerobik dihidupkan dan cek apakah udara keluar melalui difuser secara merata atau tidak. Kalau tidak merata maka perlu perbaikan difuser udara.

3. Tes pompa feed biofilter dan pompa recycle, apakah sudah dapat berfungsi dengan baik.

4. Biarkan biofill terisi hingga pompa feed biofilter dapat beroperasi secara otomatis. Atur aliran/debit pompa feed biofilter sesuai dengan kapasitas IPAL terpasang.

5. Langkah selanjutnya adalah mengisi IPAL dengan bibit atau seed mikroba atau bakteri. Seed mikroba diambilkan dari instalasi pengolahan air limbah domestik yang sudah diketahui kinerjanya berjalan dengan baik atau ditambahkan starter mikroba.

6. Selanjutnya hidupkan pompa sirkulasi, dengan demikian mikroba akan mengalir teraduk dalam IPAL, dan lama kelamaan akan lengket pada permukaan media biofilter.

7. Selama masa seeding, untuk mempercepat proses perkembangbiakan mikroba pengurai air limbah, maka perlu dilakukan penambahan nutrient. Penambahan nutrient dilakukan pagi setiap hari selama 3 minggu pertama IPAL beroperasi. Caranya adalah mengambil nutrient sebanyak $1 / 4$ kg kemudian dilarutkan kedalam air pada ember. Pastikan nutrient larut semua. Setelah itu cairan nutrient dituangkan kedalam bak pengendap awal dan bak anaerobik. Sisa padatan nutrient jangan dimasukkan ke dalam IPAL.

8. Setelah selesai masa seeding, selanjutnya dilakukan pemantauan secara kontinyu (Swa-pantau).

9. Semua Industri yang sudah memiliki IPAL diwajibkan melakukan Swa-pantau harian oleh BPLHD DKI. Yang paling mudah dan ekonomis adalah swa-pantau debit air limbah, pH, TSS dan pemantauan $\mathrm{COD}$ atau organik $\mathrm{KMnO}_{4}$.

10. Setiap 3 bulan, sampel dari inlet dan outlet IPAL harus diambil dan dianalisakan komposisinya di laboratorium independent seperti Sucofindo, Unilab dan atau di laboratorium lingkungan hidup terdekat. Hasil analisa dilaporkan ke bagian lingkungan hidup Pemda Muncar.

\section{HASIL UJI COBA}

Sebelum dilakukan uji coba yaitu melakukan pengontrolan sistem operasional di setiap unit proses dan sistem operasional secara keseluruhan. Setelah sistem dinyatakan berjalan dengan baik dan harmonis, maka dilakukan start-up operasional IPAL dengan memasukkan limbah dari kegiatan produksi dan dari kegiatan cuci unit.

Start-up ini dilaksanakan di lokasi IPAL salah satu industri pengolahan ikan ditugaskan satu orang operator lapangan yang akan melakukan pengawasan kinerja IPAL. Setelah start-up dilakukan selama 1,5 bulan, maka dilakukan pengambilan sampel limbah dan hasil olahan IPAL di setiap unit proses untuk dianalisa di laboratorium lingkungan. Sampel limbah diambil di unitunit sebagai berikut :

- Limbah segar: merupakan limbah yang berada di unit equalisasi pertama, yaitu campuran limbah dari cuci unit dan limbah dari produksi yang telah melewati oil trap.

- Limbah outlet kimia: merupakan limbah yang telah dilakukan proses 
koagulasi, flokulasi dan pengendapan lumpur.

- Outlet biologi: merupakan limbah yang telah diproses secara biologi di biofilter (outlet biofil).

- Outlet filter: merupakan limbah dari outlet biofill yang telah dilakukan filtrasi dengan saringan pasir dan saringan karbon, serta telah dibubuhi disinfektan (kaporit).

Berdasarkan hasil analisa laboratorium sampel limbah dan air olahan di setiap unit proses IPAL dapat diketahui sebagai berikut :

1. Dalam proses pengolahan limbah ini tidak dilakukan perubahan temperatur,

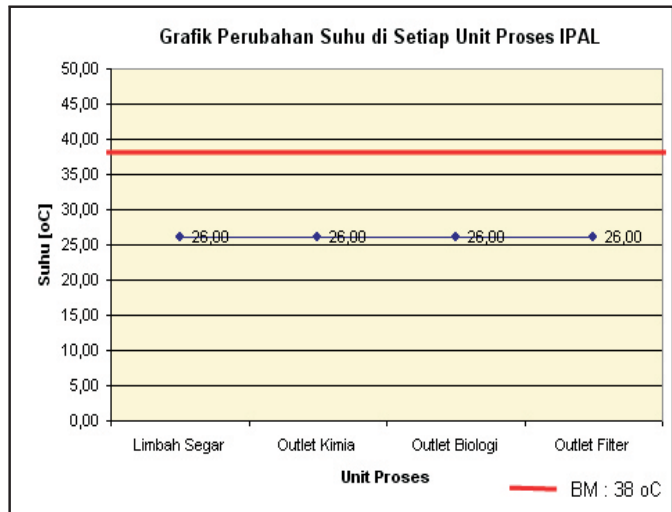

sehingga temperatur limbah di setiap unit proses relatip stabil/sama.

Gambar 6. Perubahan suhu di unit IPAL

2. Proses koagulasi, flokulasi dapat berfungsi/berjalan dengan baik, hal ini ditunjukkan dengan penurunan konsentasi TSS dari limbah segar ke outlet proses kimia yaitu dari 20.458 ppm menjadi 58 ppm (effisiensi mencapai 99,7\%). Untuk proses

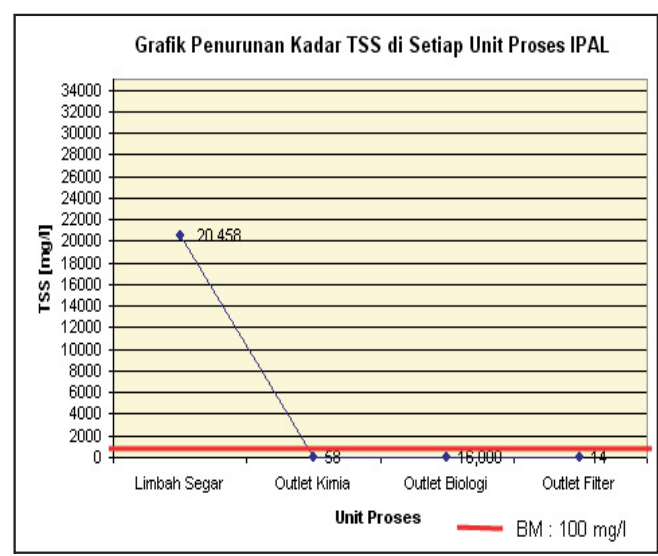

pengolahan berikutnya juga dapat menurunkan konsentrasi TSS.

Gambar 7. Penurunan TSS di unit IPAL

3. Dalam proses pengolahan limbah ini tidak dilakukan perubahan pengontrolan $\mathrm{pH}$, sebab range $\mathrm{pH}$ yang ada masih masuk dalam range yang aman dan memenuhi baku mutu limbah buangan sehingga diambil

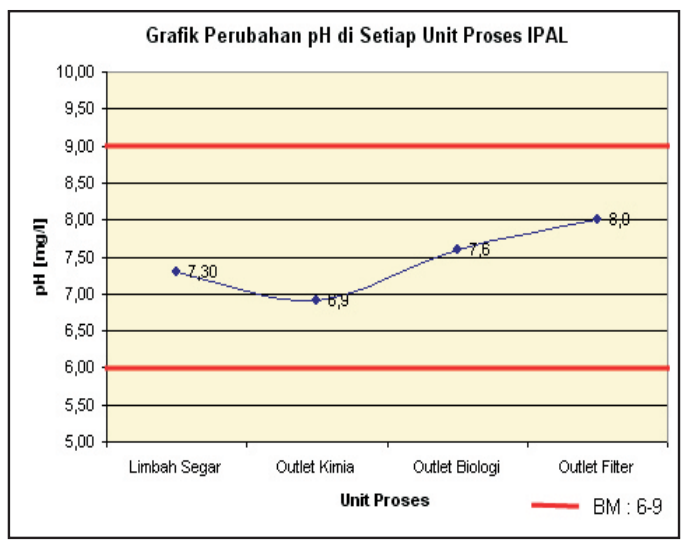

keputusan untuk tidak merubah $\mathrm{pH}$ limbah yang ada.

Gambar 8. Perubahan pH di unit IPAL

4. Kandungan nitrat pada limbah ini relatip kecil, sehingga baik di inlet 


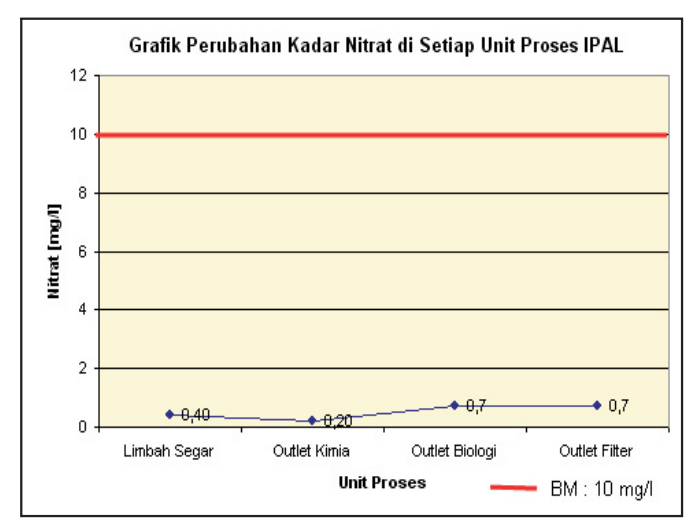

maupun outlet kandungan nitrat tidak menimbulkan masalah.

Gambar 9. Perubahan Nitrat di unit IPAL

5. Konsentrasi COD limbah inlet cukup tinggi (12.656,2 ppm), namun setelah proses pengendapan nilai COD jauh menurun $(138,1 \mathrm{ppm})$. Hal ini menunjukkan bahwa banyak sekali bahan kimia maupun organik di limbah yang telah dapat dihilangkan bersama dengan padatan yang ada di dalam limbah. Di proses biofilter juga terjadi penurunan nilai COD menjadi 30,3 ppm (tingkat effisiensi proses 78\%) yang berarti mikroba yang ada di dalam biofilter ini telah aktif bekerja dengan baik. Setelah proses filtrasi nilai COD turun menjadi 20,7 ppm, yang berarti ada proses penyaringan dan penyerapan di dalam filter-filter yang terpasang. Nilai outlet ini sudah

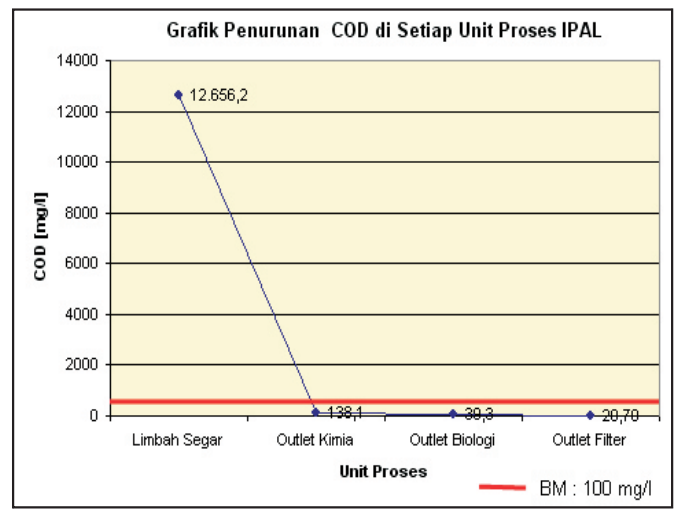

jauh sangat memenuhi baku mutu yang diberlakukan (BM = 100 ppm).

Gambar 10. Penurunan COD di unit IPAL

6. Konsentrasi BOD limbah inlet juga cukup tinggi $(4.890,8 \mathrm{ppm})$, namun setelah proses pengendapan nilai BOD jauh menurun (35,6 ppm). Hal ini menunjukkan bahwa banyak sekali bahan kimia maupun organik di limbah yang telah dapat dihilangkan bersama dengan padatan yang ada di dalam limbah. Di proses biofilter juga terjadi penurunan nilai BOD menjadi 9,9 ppm (tingkat effisiensi proses $72,2 \%$ ) yang berarti mikroba yang ada di dalam biofilter ini telah aktif bekerja dengan baik. Setelah proses filtrasi nilai BOD juga turun menjadi 5,2 ppm, yang berarti ada proses penyaringan dan penyerapan di dalam filter-filter yang terpasang. Nilai outlet ini sudah jauh

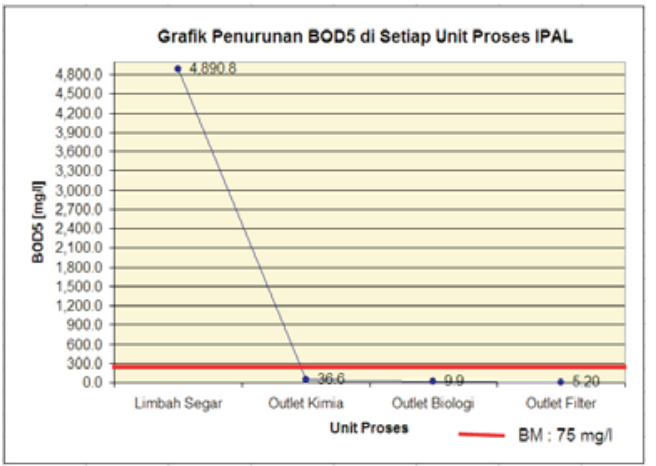

sangat memenuhi baku mutu yang diberlakukan (BM $=75 \mathrm{ppm})$.

Gambar 11. Penurunan BOD5 di unit IPAL

7. Proses koagulasi, flokulasi dan pengendapan juga berfungsi/berjalan dengan baik untuk menghilangkan kadar logam (besi) yang ada di dalam limbah. Hal ini ditunjukkan dengan penurunan konsentasi $\mathrm{Fe}$ dari limbah segar $(21,4 \mathrm{ppm}) \mathrm{ke}$ outlet proses kimia menjadi 1,67 ppm (effisiensi mencapai 92,2\%). Untuk proses pengolahan berikutnya juga dapat menurunkan konsentrasi Fe 


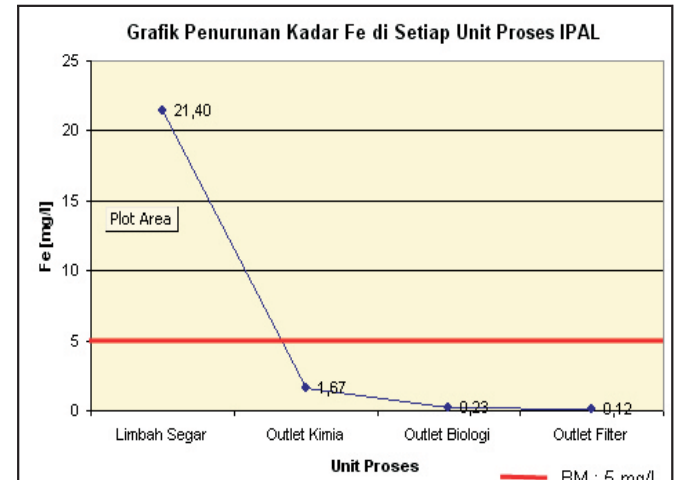

yang ada. Nilai outlet ini sudah jauh sangat memenuhi baku mutu yang diberlakukan (BM $=5 \mathrm{ppm})$.

Gambar 12. Penurunan Fe di unit IPAL

8. Proses koagulasi, flokulasi dan pengendapan juga berfungsi/berjalan dengan baik untuk menghilangkan kadar logam ( $\mathrm{Zn}$ ) yang ada di dalam limbah. Hal ini ditunjukkan dengan penurunan konsentasi Zn dari limbah segar $(0,47 \mathrm{ppm})$ ke outlet proses kimia menjadi 0,06 ppm (effisiensi mencapai $87,2 \%$ ). Nilai outlet ini

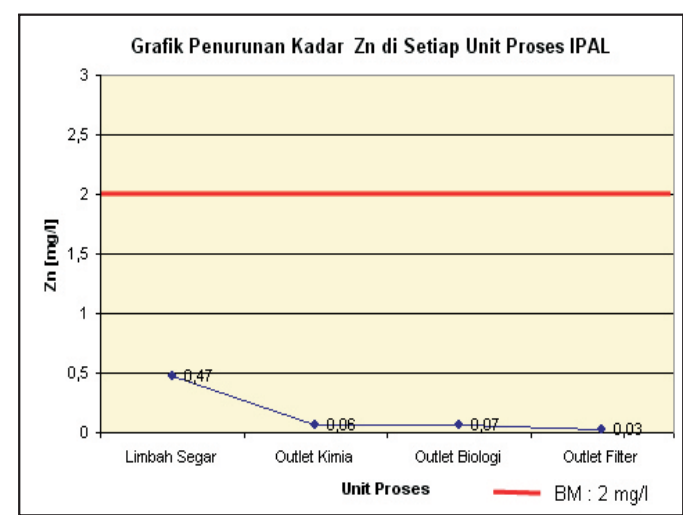

sudah jauh sangat memenuhi baku mutu yang diberlakukan $(B M=2$ ppm).

Gambar 13. Penurunan Zn di unit IPAL

9. Proses koagulasi, flokulasi dan pengendapan juga berfungsi/berjalan dengan baik untuk menghilangkan kadar minyak dan lemak yang masih tersisa dari proses oil trap. Hal ini ditunjukkan dengan penurunan konsentasi minyak dan lemak dari limbah segar (427,5 ppm) ke outlet proses kimia menjadi 0,6 ppm (effisiensi mencapai 99,8\%). Nilai outlet ini sudah jauh sangat memenuhi

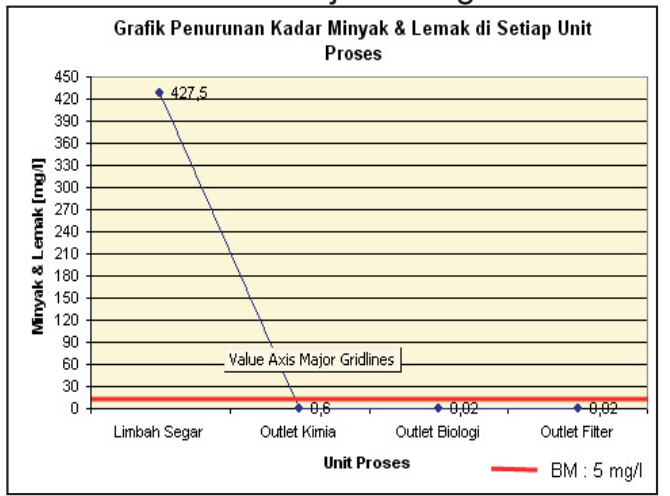

baku mutu yang diberlakukan $(\mathrm{BM}=$ $5 \mathrm{ppm})$.

Gambar 14. Penurunan minyak \& lemak di unit IPAL

\section{KESIMPULAN}

Beberapa kesimpulan dapat diambil antara lain yaitu:

1. Hasil analisa limbah menunjukkan bahwa karakteristik limbah produksi tepung ikan lebih buruk daripada limbah produksi pengolahan ikan sardin. Hal ini disebabkan penggunaan air pada proses produksi tepung ikan menggunakan air lebih sedikit daripada proses produksi pengolahan ikan sehingga air limbah produksi tepung ikan relatif lebih pekat.

2. Hasil analisa kualitas di badan Kali Mati sebelum dan sesudah air kali bercampur dengan air limbah pabrik, menunjukkan bahwa pencemaran limbah terjadi di Kali Mati setelah pabrik disekitar sungai membuang limbahnya. 
3. Proses prototipe pengolahan IPAL ini adalah gabungan proses kimia-fisika dan proses biologis dengan kombinasi proses biofilter anaerob dan aerob dengan kapasitas olah $5 \mathrm{~m} 3$ perhari.

4. Pengujian dilakukan selama 1,5 bulan dengan hasil uji coba sbb:

a. Terjadi efesiensi penurunan kadar jumlah zat terlarut (TSS) sebesar 99,7\% pada outlet proses kimia.

b. Konsentrasi COD dan BOD turun drastis menjadi dibawah Baku Mutu setelah melalui proses pengendapan dan proses biologis.

c. Efisiensi penurunan konsentrasi Fe dan kadar logam Zn mencapai diatas $90 \%$ dan hasilnya dibawah Baku Mutu.

d. Begitupun efisiensi penurunan konsentrasi minyak dan lemak dari hasil proses oil trap mencapai $99,8 \%$

Secara umum hasil ujicoba prototipe IPAL pengolahan ikan yang telah dilakukan dapat menurunkan limbah polutan dengan efiisiensi yang sangat signifikan (>90\%).

\section{DAFTAR PUSTAKA}

1. -------------"Laporan Verifikasi Kasus Pencemaran Kalimati MuncarBanyuwangi" Kantor Kementerian Lingkungan Hidup, tahun 2006.

2. Setiyono, S. Yudo, "Laporan Akhir Prototipe Alat Pengolah Limbah Industri Pengolahan Ikan di Muncar, Kab. Banyuwangi”, BPPT, 2006.

3. Said, N.I. (2000). "Pengolahan Air Limbah dengan Proses Biofilter Anaerob-Aerob". Jurnal Teknologi Lingkungan, BPPT. Jakarta.

4. Benefield, Larry, D and Randal, Cliiford.W. (1990), "Biological Proccesses Design For Wastewater Treatment". Prentice Hall, New York. 